\title{
Elderly's Expectations of Services in Integrated Health Post (Posbindu): A Qualitative Study
}

\author{
Destyana Wulandari Azana, ${ }^{1}$ Sharon Gondodiputro, ${ }^{2}$ Didah $^{2}$ \\ ${ }^{1}$ Faculty of Medicine Universitas Padjadjaran, Indonesia, \\ ${ }^{2}$ Department of Public Health Faculty of Medicine Universitas Padjadjaran, Bandung, Indonesia
}

\begin{abstract}
Many factors influence the compliance of the elderly to visit the Integrated Health Post (posbindu). One factor that needs to be explored is the expectation of the elderly on the services in this post. Expectations that are met with performance will create satisfaction, leading to a regular visit to the posbindu. This study aimed to explore the expectations of the elderly towards services provided in the posbindu. A qualitative phenomenology study using a in-depth interview was conducted to 8 elderly informants from 7 posbindu from 7 public health centers (Pusat Kesehatan Masyarakat, Puskesmas) who were selected by purposive sampling in Bandung City. Posbindu and Puskesmas was selected in a simple random manner. The study was conducted from July to October 2018. Explored concepts were structure, process, and output of expectations. The collected data was processed by coding and categorization. This study discovered that the structural expectation covered three subthemes, namely accessibility, human resources, and facilities. The process expectation was formed by three subthemes: behavior and communication skills of the cadres; behavior and communication skills of the health providers; consultation and treatment. The output expectation was formed by three categories, including information about their illness, controlled disease, and the desire to stay healthy. This study discovered 3 new categories from several subthemes of the health care provided in the posbindu, i.e. free services, attendance of a doctor, and medicine prescription. In conclusion, the expectation of the elderly towards the health services at the Posbindu has been identified.
\end{abstract}

Key words: Elderly, expectation, posbindu

\section{Ekspektasi Lansia terhadap Pelayanan di Posbindu}

\begin{abstract}
Abstrak
Banyak faktor yang mempengaruhi kepatuhan lansia untuk datang ke Pos Pembinaan Terpadu (Posbindu). Salah satu faktor yang perlu digali adalah harapan para lansia. Harapan sesuai dengan kenyataan akan menciptakan kepuasan, yang mengarah ke kunjungan rutin ke Posbindu. Tujuan dari penelitian ini adalah mengeksplorasi harapan para lansia terhadap layanan di Posbindu. Penelitian fenomenologis kualitatif dilakukan dengan menggunakan wawancara mendalam kepada 8 informan lansia dari 7 Posbindu (dari 7 Puskesmas) yang dipilih secara purposive sampling di Kota Bandung. Pemilihan Posbindu dan Puskesmas dilakukan secara acak sederhana. Studi ini dilakukan dari Juli hingga Oktober 2018. Konsep yang dieksplorasi adalah struktur, proses, dan output dari harapan. Data yang dikumpulkan, diproses dengan pengkodean dan kategorisasi. Penelitian ini menemukan harapan struktural dicakup oleh tiga sub-tema, yaitu aksesibilitas, sumber daya manusia, dan fasilitas. Harapan proses dibentuk oleh tiga sub-tema, yaitu perilaku dan komunikasi kader; perilaku dan komunikasi tenaga kesehatan; konsultasi dan perawatan. Harapan masukan dibentuk oleh tiga kategori, termasuk informasi tentang penyakit mereka, penyakit terkendali, dan keinginan untuk tetap sehat. Studi ini menemukan 3 kategori baru dari beberapa subtema yaitu tidak perlu membayar, kehadiran dokter, dan pemberian obat. Simpulan, harapan lansia terhadap layanan kesehatan di Posbindu telah diidentifikasi.
\end{abstract}

Kata kunci: Ekspektasi, lansia, posbindu

Corresponding Author: Sharon Gondodiputro. Department of Public Health Faculty of Medicine Universitas Padjadjaran, Jalan Prof. Eyckman No. 38, 40161, Bandung, West Java, Indonesia. Email: sharon_gondodiputro@yahoo.com 


\section{Introduction}

The elderly is prone to many chronic diseases. ${ }^{1}$ However, this is not an obstacle for them to undergo their routine activities and their roles in their community. The perception towards the role of the elderly in doing their routines and and in the community should be shifted from resource consumers to resource providers and from social burden to social asset. ${ }^{2}$ One of the factors that contribute to this perception is the availibility of a community support to encourage the elderly to be active and productive., ${ }^{2,3}$

The Integrated Health Post (posbindu) for the elderly is a form of social support directed towards the health of the elderly. The posbindu is an expansion of posyandu, a health post formed by the community in the village level to provide health services to babies, toddlers, and pregnant women. ${ }^{4,5}$ The purpose of posbindu is to increase interactions among the elderly; to provide promotive and preventive health services according to the needs of the elderly; and to encourage the elderly to be active, independent, and productive. ${ }^{5}$

The utilization of posbindu by the elderly is still low. Many factors are suspected to cause this situation, including inadequate knowledge of the elderly and the cadres; inadequate health services provided at the posbindu; lack of health provider and family support; distance between the houses of the elderly to the posbindu; low frequency of counselling; and an unsympathetic services. ${ }^{6,7}$ A study on the expectation of the elderly towards health services in the Posbindu has not been carried out. Expectation is a potential predictor for satisfaction, meaning that if the elderly are satisfied with the health services provided in the posbindu, they will visit the posbindu regularly. ${ }^{8,9}$

The definition of the elderly's expectations towards the services in the posbindu has not yet been constructed but the definition of expectation itself can be adapted from the definition of expectation towards health services from Levenstein: "the individuals" stated reasons for the visit, that often relate to a symptom or a concern, which is anticipated for an acknowledgement or a response from the physician". ${ }^{10}$

The classification of expectation is in an undergoing debate. Rotter divides expectations into two parts, general and specific expectations. ${ }^{8}$ General expectations are expectations of patients who have no experience in receiving healthcare services while specific expectations are expectations of patients with experience in receiving healthcare services. ${ }^{8}$ Other classifications include expectations associated with structure (infrastructure, instruments, and human resources), process (waiting time and health professional interaction with patients), and output (effects of healthcare services towards the health of the patients). ${ }^{8}$ According to Bowling and Rome, ${ }^{8}$ six items contribute to expectations: 1) structure of health care, 2) process of health care, 3) doctor-patient communication style, 4) consultation and treatment/procedures, 5) doctors' approach to information, and 6) treatment outputs.The components of the elderly's expectations towards services in the posbindu also include the availability of human resources and facilities.Hence, this study aimed to explore the expectations of the elderly towards health services provided in posbindu.

\section{Methods}

A qualitative study with a phenomenology approach using in-depth interviews with 8 elderly from Bandung City, West Java Province was performed. A qualitative method was selected in order to explore new information and further comprehend what the elderly expects from services in posbindu to make them willing to do regular visits. This study was conducted from July to October 2018. Simple random sampling was applied to choose 7 Public Health Centers (Pusat Kesehatan Masyarakat, puskesmas) and 7 posbindu from each puskesmas. From each posbindu, 1-2 informants were selected using purposive sampling, with the following inclusion criteria: aged above 60 years, male and female, a minimum of one visit to posbindu recorded in the last three months, has the ability to communicate fluently (no physical or mental disability hampering communication, no dementia as detected using Mini Mental State Examination (MMSE) with a total score of $>23$ for the elderly whose educational background was senior high school or below and $>25$ for the elderly whose educational background was higher than senior high school.

Before conducting interviews with the informants, a semi-structured questionnaire was adapted and developed from a questionnaire by Bowling and Rome ${ }^{8}$ and health service guide in the posbindu $u^{5}$ with no limitations on the emerging new concepts from the informants. The questionnaire consisted of 18 items, including 4 general items, 7 items regarding structural 
expectations, 6 items regarding process expectations, and 1 item regarding output expectations. The 4 general items or questions asked about the frequency of visits to the posbindu in the last 3 months, reason for visiting posbindu, satisfaction or dissatisfaction towards the services, and reasons for satisfaction or dissatisfaction. Items on structural expectations questioned about accessibility (schedule, frequency and operating time), room conditions, facilities, and cadre and health professional availability. Items on process expectations asked questions on waiting time, service provided by cadres (friendliness, helpfulness, respectfulness, adequate knowledge, and understandable explanations), information, examination in coherence to their needs, health services provided by health providers, and expectation towards health services in posbindu. The item on expectations from the output perspective questioned about the expectation after receiving health care at the posbindu.

Permission to do the study was obtained from three institutions, namely the Bandung City Mayor Office, Bandung City Health Office, and the selected puskesmas. This study had received the ethical clearance from the Ethics Committee of Universitas Padjadjaran Bandung, Indonesia under the ethical clearence No. 708/UN6.KEP/ EC/2018.

Data collection was conducted in the informants' homes. Throughout the interview, the interviewer started by asking the general questions, followed by other questions regarding expectations. Additional questions and explanations, if necessary, were given to lead informants to answer within the contexts of the expectations. The interviewer also gave the opportunity to the informants to suggest a new concept of their expectations towards the services provided by the posbindu as long as it was in coherence with the concept of structural, process, and output expectations. Responses were checked during the interview process by restating the information given by the informants to determine the accuracy of it. The interview was conducted in 20-30 minutes.

One of the researchers made the transcripts of the interviews and printed them and shared them with the two other researchers. A debriefing method was held among the researchers. The main researcher led the meeting to conduct content analysis to detect statements that support the expectation of the elderly towards the services in the posbindu. Each researcher conducted coding independently based on keywords from the questions list (predetermined codes) and, if a new concept was found, a new code (emerging code) was assigned. The coding results were discussed among the three researchers. If there was a disagreement over a code, an in-depth discussion was conducted to reach a consensus for the selected code. The codes were then organized into categories and substantial subthemes.

\section{Results}

The study participants consisted of 2 males and 6 females who visited posbindu regularly. Most participants were between 60 and 65 years old and only one participant was 75 years old. The majority of the participants had a senior high school degree. Results showed that structural expectations consisted of 3 subthemes: accessibility, human resources, and facilities (Table). It was discovered that that the Posbindu location was relatively close to the home of all informants, making it easy to access. All informants stated that the posbindu schedule, i.e. its frequency and operating schedule, was in accordance with their expectations. A posbindu that was opened more than once a month would be a troublesome to them since they had other activities to attend. Operating hours of the Posbindu that was set in the morning was suitable for them because most of the informants were retired. This study discovered a new category from the accesibility subtheme., which was "do not have to pay".. They were eager to come to the Posbindu because the medical examination and the laboratory test provided at the Posbindu were free of charge. They mentioned that if they had to go to a private practice or to a laboratory, they had to pay a sum of money, as the following informants stated :

"Satisfied because there is a blood test. If you go to the laboratory you have to pay and it is expensive. Here, in posbindu, you don't have to pay" (Informant 3)

"Yes, I don't have to go to the private doctor because if I go there, I have to pay" (Informant 7)

The study also discovered that most of the informants stated that every time the Posbindu opened, several cadres were available. Health providers that often came from the Puskesmas midwives and nurses. They expected that a medical doctor would also provide service there. Several informants stated that the facilities in the posbindu were adequate. The rooms used 
for the posbindu were comfortable and clean enough. This was due to the fact that every time the posbindu was scheduled to open, the rooms in the multi-purpose hall would be cleaned prior to the operating hours. Most of the informants stated that the medical checkup tools used to measure blood pressure, weight, and height were adequate

Process expectation was formed by three subthemes: behavior and communication skills of the cadres; behavior and communication skills of health providers; and consultation and treatment (Table). This study discovered that several informants did not have to wait long to obtain the healthcare service and did not complain if they must wait in line for a while to wait for their turn for examination. This situation depended on the number of the elderly's presence. When only a few came, the service could be done swiftly, but when there were many people, they might have to wait for around one hour as described below:

"We are waiting for our turn. Who comes first will be examined first and those who come

later will be examined later" (Informant 2)

Most informants conveyed their satisfaction

\section{Table Expectations (Structure, Process, and Output) of Elderly towards Services at Posbindu}

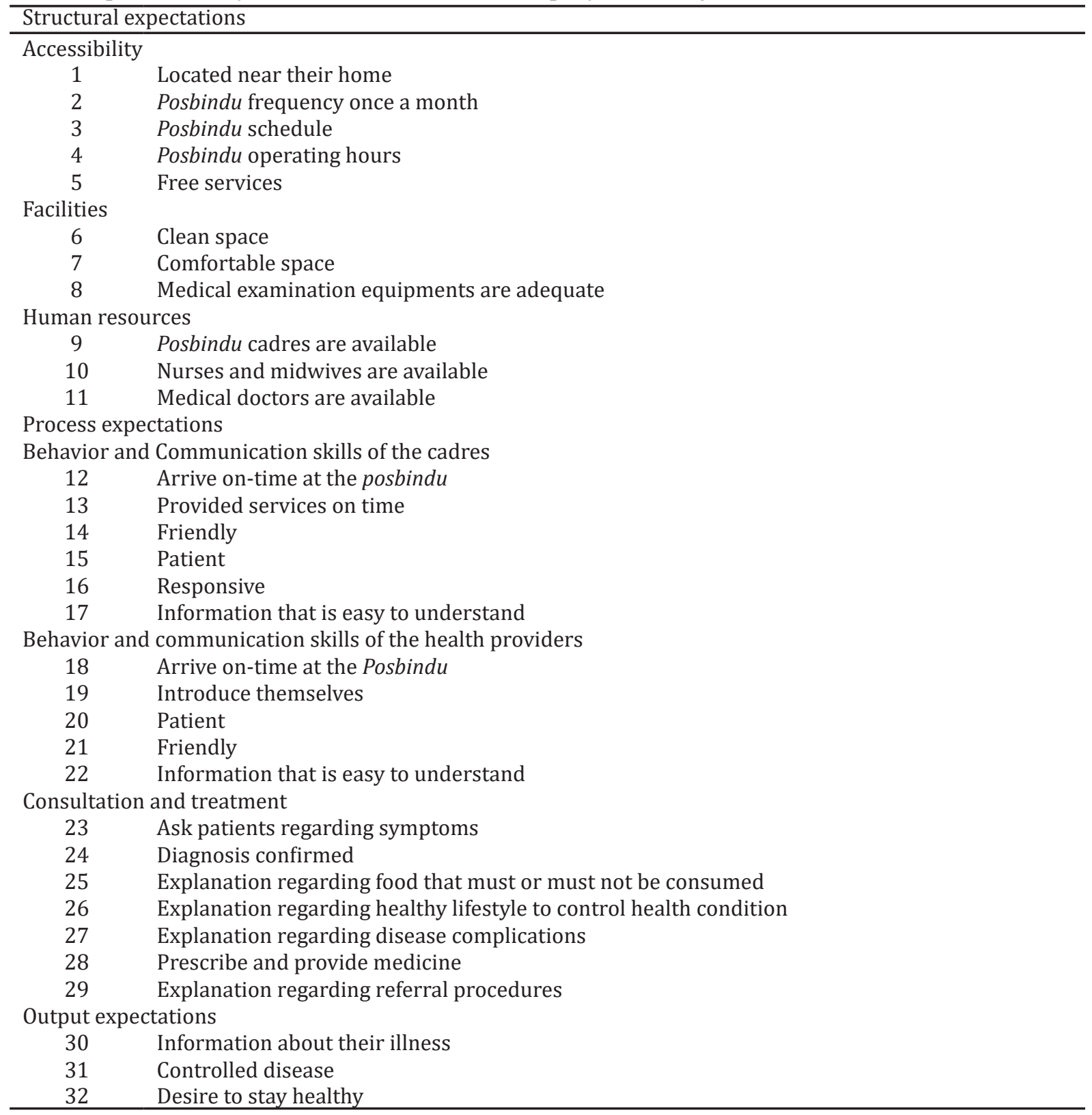


towards the service provided by the cadres. They stated that the cadres were always on-time, friendly, active, patient, and responsive. When the elderly arrived at the posbindu, the cadres immediately greeted them and guided them to have their body weight and height measured. Moreover, the informants mentioned that the cadres explained everything using a language that was easy to understand and when the informants did not understand something, the cadres were eager and patiently explain until the informants understood, even though that meant explaining more than one time.

Regarding the behaviour and communication skills of the health providers, most informants stated that the health providers were present on time and they were also patient, active, and able to give explanation in an easy-to-understand manner. Sometimes the informants did not know whether the health providers who came to the Posbindu was a medical doctor or a nurse. They expected that the health providers introduced themselves or wore an identity card. The informants stated:

"I don't know who they are, I think there are two health providers coming from the puskesmas" (Informant 3)

"I think she was a doctor but there were two health providers, one who examined me and the other measure a test. I think they should introduce themselves" (Informant 8)

The study also discovered that the health providers always asked about symptoms of the informants' illnesses and if they already had information about the informants' illnesses beforehand, the health providers confirmed it. In explaining the illnesses, most informants confirmed that the health providers used a language that was easy to understand.

Consultation provided by health professionals also included information on healthy food and lifestyle to control diseases and complications that may be experienced when a disease was not controlled. For examples, the health professional explained to the hypertensive patients, not to eat food that had a high salt content and also to stop smoking. In obesity case, the health providers asked the patients to start losing weight.

This study also discovered that the informants expected the health providers to prescribe and provide medicine. The informants stated that since the posbindu was near their home, it was practical to have their regular medicine at the posbindu so that they did not have to go to the puskesmas every time they need the medicine, as the following informants described:
"If I was sick I could get the medicine at the posbindu" (Informant 7)

"I expected that when I came to the posbindu the health providers could give me medicine" (Informant 8)

The output expectation was formed by three categories, including information about their illness, controlled disease, and the desire to stay healthy (Table 1). This study discovered that by attending the Posbindu routinely, the informants knew about their illness and also knew whether their illness was controlled or not. If they knew that their illness was controlled, they felt relieved and happy. At the posbindu, they received various information to be and stay healthy. The informants wished to stay healthy:

"At the posbindu, the health providers check my blood pressure whether it is normal or not; the information my blood pressure makes me feel at ease. If I don't check it every month I'm afraid that my blood pressure will be high" (Informant 1)

"I want to be healthy eventhough I'm old" (Informant 6)

"I want to be healthy and to know about my health condition" (Informant 8)

\section{Discussion}

The Integrated Health Post (posbindu) for the elderly is one of the forms of social participation for the elderly in the health sector which is organized by the local community. In its implementation, the posbindu is managed by cadres and is assisted by the puskesmas in providing healthcare services by assigning health providers such as medical doctors, midwives, or nurses. ${ }^{5}$ The posbindu is scheduled for a minimum of once a month and its activities include registration, record of daily activities, as well as weight and height measurement, all done by the cadres. Health providers will measure blood pressure as well as conducting medical checkup, mental health checkup, and simple laboratory test followed by counselling. In Posbindu, health providers are not allowed to prescribe and provide medicine. ${ }^{5}$

The expectation of the elderly towards services in posbindu is an important factor to measure satisfaction. ${ }^{11}$ The level of satisfaction is measured from the gap between expectation and performance in using a product/service. ${ }^{11,12}$ The level of satisfaction can be reflected in patients' compliance towards medication, patients' activeness in managing their health, 
and patients' continuity in visiting a healthcare facility. From the perspective of the health providers, understanding the level of patient satisfaction may help them to further improve their healthcare services. ${ }^{13}$

This study has succeeded in specifying the expectation of the elderly into three themes, i.e. structure, process, and output expectations. The structural components forming the elderly' expectations consisted of three subthemes, i.e. accessibility, human resources, and facilities Accessibility to posbindu plays an important role. A posbindu located nearby their homes will make them more willing to visit the posbindu. ${ }^{14,15}$ The elderly are prone to many chronic diseases, especially hypertension. Posbindu that is scheduled to be held once a month can be utilized by the elderly to measure their blood pressure regularly and to identify risk factors for other diseases in order to begin taking preventive and promotive actions. ${ }^{5}$ One of the new categoriesof the accessibility subtheme discovered in this study is "fee service" category. Services provided by the posbindu is free of charge. This is advantageous for the elderly. Not all of elderly have the money to pay for healthcare services. In Indonesia, most (45.14\%) elderly live under the poverty line. ${ }^{16}$

Cadres play an important role in managing the posbindu. They are tasked to encourage the elderly to visit the posbindu, measure their weight and height, and perform health counselling. ${ }^{5}$ The cadres are assisted by health providers such as midwives, nurses, or medical doctors assigned from the Puskesmas.

Health providers are responsible for blood pressure measurement, mental health checkup, laboratory test, and counselling. ${ }^{5}$ This study discovered that medical doctors are not always available in posbindu. The complex health condition of the elderly is not an issue that can be solved by the midwives or nurses. The elderly expected that a medical doctor should be available at the posbindu. The presence of a health provider to improve the attendance of the elderly is still controversial. A study by $\mathrm{AE}$ Arimby and Apriningsih ${ }^{14}$ discovered that the support of the health providers towards the Posbindu had a significant relationship to the presence of the elderly at the posbindu. On the contrary, a study by Alhadiyati ${ }^{15}$ discovered that there is no relationship between the presence of the health providers and the elderly visits to posbindu.

The process expectations were constructed of three subthemes: behavior and communication skills of the cadres; behavior and communication skills of health providers; and consultation and treatment. This study discovered that several informants did not have to wait long to obtain their service Waiting time is the time that the patients have to wait until they can receive in obtaining healthcare services, starting from registration to entering the doctor's examination room. Patient waiting time is one of the many components causing dissatisfaction. ${ }^{17}$

The behavior of cadres or health providers towards elderly affects their expectations to visit the posbindu. This study revealed that the elderly were satisfied with the behavior of cadres or health providers who were patient, friendly, and responsive. Friendliness in the healthcare service corresponds directly to the activeness of the elderly's visit to the posbindu, as it cultivates trust and affects satisfaction. ${ }^{18}$ Health providers are health facilitators who play a role in the execution of activities in posbindu. They provide health counselling and motivation for elderly. ${ }^{5}$

The communication between cadres or health providers and the elderly is also another important factor. Communication is one of the factors that leads to their satisfaction towards the received care. ${ }^{19} \mathrm{~A}$ well-established communication will also lead to patients' compliance towards treatment-related advices conveyed by health profesionals. The elderly consider communication with their health providers as an important thing, because they believe that these health providers are important sources of information regarding their illnesses. ${ }^{19} \mathrm{~A}$ lot of factors may cause an unsuccessful communication, including the fact that the elderly quickly forget what they were told, did not have enough knowledge regarding health, and complicated language used by health providers. ${ }^{19}$ This study showed that the elderly expected the cadres and the health providers to provide information regarding their health in an easy-to-understand manner.

This study discovered that elderly expected the health providers to ask about their illnesses and tell them about the way to control it through dietary habits and healthy lifestyles. One of the components of the elderly' satisfaction is the provision of information that is in accordance to their conditions. ${ }^{20}$ Health information is an important part of the service given in the posbindu because it can improve the elderly's knowledge to control their diseases. This study also discovered that elderly expect to be given medicine in posbindu, although this facility only provides promotive and preventive services. ${ }^{5}$ 
The output expectations are constructed of three categories, information about their illness, controlled disease, and the desire to stay healthy. This study revealed that after the elderly attended the Posbindu, they knew about their health condition and it gave them a relief. Moreover, most informants stated that their diseases were controlled. Finally, the elderly expected to be and stay healthy. These output expectations were in accordance with a study by Bowling. ${ }^{8}$

This study had several limitations. During the interviews, there were several informants who answered the questions incoherently especially when answering questions about output expectations. The researcher had to explain the meaning of the questions repeatedly until they understood. This situation made the researcher had to probe the three categories of output expectations to them. This study also did not make observation on posbindu activities. Despite these limitations, this study provides a strong understanding about the elderly's expectations towards services in posbindu that has never been studied before. Identification of these expectations can be used as the basis for developing a measuring instrument in the form of a questionnaire that can be tested for its reliability and validity. It can be concluded that the expectation of the elderly towards services in the posbindu is constructed of three themes, namely structure, process, and output. This study discovered 3 new categories of several subthemes, namely the free service under the category of the accesibility subtheme, the attendance of a doctor in the category of the human resource subtheme; and the medicine prescription in the category of the consultation and treatment subtheme.

\section{References}

1. World Health Organization. World report on health and aging. Geneva: WHO; 2015.

2. Villar F. Successful ageing and development: the contribution of generativity in older age. Ageing Soc. 2012;32(7):1087-105.

3. Hajek A, Brettschneider C, Mallon T, Der Leeden C Van, Mamone S, Wiese B, et al. How does social support affect functional impairment in late life? Findings of a multicenter prospective cohort study in Germany. Age Ageing. 2017;46(5):813-20.

4. Pratono AH, Maharani A. Long-term care in Indonesia: The role of integrated service post for elderly. J Aging Health. 2018;30(10):1556-73.

5. Indonesian Ministry of Health. Pedoman pengelolaan kegiatan kesehatan di kelompok lanjut usia. Jakarta: Kemenkes; 2010.

6. Suparto, TA, Sunjaya DK, Susanti R. Factors that affect posbindus' performance in Dayeuhkolot Kabupaten Bandung. J Phys Conf Ser. 2016;755(1):1-6.

7. Arpan I, Sunarti S. Faktor frekuensi kunjungan lansia ke posyandu lansia di Kecamatan Pontianak Timur. J Vokasi Kesehat. 2017;3(2):92.

8. Bowling A, Rowe G. Psychometric properties of the new patients ' expectations questionnaire. Patient Exp J. 2014;1(1):11130.

9. Ahmed S, Tarique KM, Arif I. Service quality, patient satisfaction and loyalty in the Bangladesh healthcare sector. Int J Health Care Qual Assur. 2017;30(5):477-88.

10. Williams S, Weinman J, Dale J, Newman S. Patient expectations: What do primary care patients want from the GP and how far does meeting expectations affect patient satisfaction? Fam Pract. 1995;12(2):193201.

11. Qazi A, Tamjidyamcholo A, Raj RG, Hardaker G, Standing C. Assessing consumers' satisfaction and expectations through online opinions: Expectation and disconfirmation approach. Comput Human Behav. 2017;75(2017):450-60.

12. Jaworski $M$, Rzadkiewicz $M$, Adamus $M$, Chylinska J, Lazarewicz M, Haugan G, et al. Primary care patients' expectations regarding medical appointments and their experiences during a visit: Does age matter? Patient Prefer Adherence. 2017;11:1221-33.

13. Asadi-Lari M, Tamburini M, Gray D. Patients' needs, satisfaction, and health related quality of life: Towards a comprehensive model. Health Qual Life Outcomes. 2004;2:1-15.

14. Arimby A, Apriningsih. Determinan kunjungan lansia ke Posbindu Senja Sejahtera Cinere, Depok tahun 2015. 2016;12(1):42-54.

15. Alhidayati. Faktor-faktor yang berhubungan dengan perilaku kunjungan lansia ke posyandu lansia di Puskesmas Kampar Kabupaten Kampar Tahun 2013. J Kesehat Komunitas. 2014;2(5):220-4.

16. Madyaningrum E, Chuang YC, Chuang KY. Factors associated with the use of outpatient services among the elderly in Indonesia. BMC Health Serv Res. 2018;18(1):707. 
17. Michael M, Schaffer SD, Egan PL, Little BB, Pritchard PS. Improving wait times and patient satisfaction in primary care. J Healthc Qual. 2013;35(2):50-60.

18. Wahyuni ID, Aini A, Rahmiwati A. Analysis of elderly participation in health development activities at the working area of Puskesmas Sekarjaya Ogan Komering Ulu Regency. Jurnal Ilmu Kesehatan Masyarakat. 2016;7(2):96107.
19. Koops van 't Jagt R, de Winter AF, Reijneveld SA, Hoeks JCJ, Jansen CJM. Development of a communication intervention for older adults with limited health literacy: photo stories to support doctor-patient communication. J Health Commun. 2016;21(Suppl2):69-82.

20. Tamsuri A, Arismadani Y. Gambaran tingkat kepuasan lansia terhadap pelayanan posyandu lansia. AKP. 2014;5(2):39-47. 